\title{
INMB
}

JSMB Vol. 6 (1) 2019 hlm. 31-34

Jurnal Studi Manajemen dan Bisnis

http://journal.trunojoyo.ac.id/jsmb

\section{The Effect Of Work Culture On The Improvement Of Work Performance Of Dispora Employees Lamongan Regency}

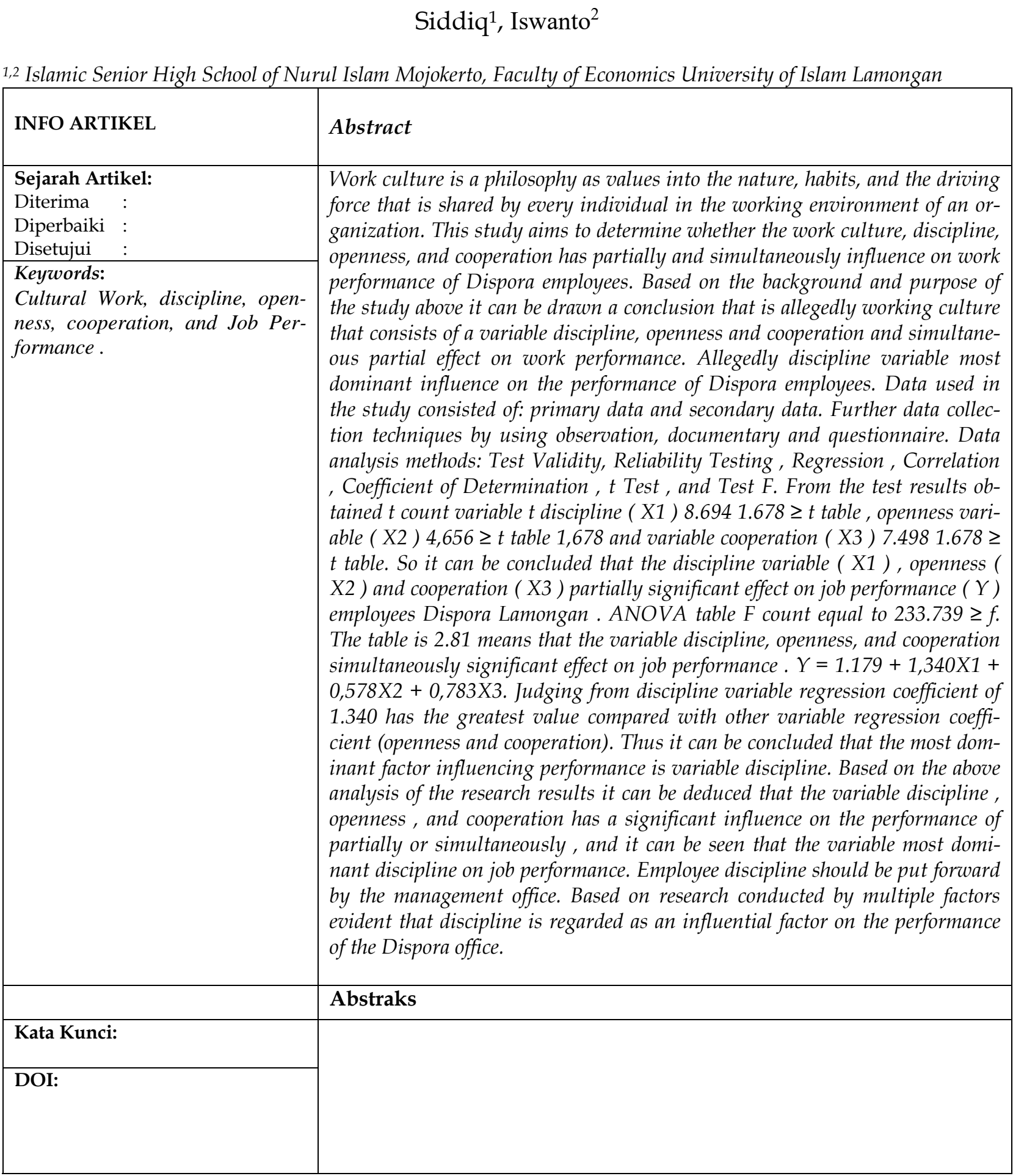




\section{INTRODUCTION}

Strategic environmental development of national and international confronted today and in the future hint change the paradigm of governance, reform the institutional system, improvement of human resources competencies in governance and nation building as well as the relations between nations that lead to the implementation of good governance ( good governance).

The phenomenon of fundamental change that is manifested by giving birth to Law Number 22 Year 1999 on Regional Government and Law No. 43 of 1999 on the Principles of Civil Service has given the direction of change in governance and staffing of civil servants who have direct implications for the readiness of development human resources, and the availability of other resources. The quality of human resources is an important factor in achieving successful development. Experience of Asian countries such as Japan, Taiwan and Singapore prove this fact. The advantages of these countries on their natural wealth but on the human resources at their disposal. Efforts to improve the quality of human resources continuously developed and is accompanied by an increased understanding of the work. Without understanding the work then any work performed which may affect the narrow selfinterest and does not lead to the interests of the company / institution. This means that a work is limited to his personal needs. With the understanding that the low quality of work it will have an impact on the contribution of human resources also lower. Vice versa, if a working understanding high, it will have an impact on the contribution of human resources is high.

Work Culture is a way of living ( cultivation + power $=$ cultivation $)$ as well as the human way of life which is based on a view of life which is based on the value of excellent manners generally accepted and has become nature, habits and the driving force that gives positive energy in humans to always succeed in the work. Work Culture as human capital, should be used as a guide in the assessment, either as a criterion in the policy formulation and decision-making policies in Human Resources Management, as well as an attitude present themselves in the overall dimensions of service activities. (Sedarmayanti 2014: 77 )

According to Edi Sutrisno $(2011: 2)$ The work culture can be defined as the system of values ( values) beliefs ( believe ) assumptions ( assumptions ) or norms which have a longstanding, which have long been agreed and followed by the members of the organization as a code of conduct and problems solvers organization.

Work culture is a concept that is very varied, as is evidenced by the many definitions of a very different that can be found in the literature. This is caused by a variety of views, approaches, and interests of each interested from various academics and practitioners. Besides, it is also because the source, is the discipline of anthropology, until now have not been able to produce a definition that can be received by enthusiasts or experts in this field (Koentjraningrat , 2011: 6-7).

Work Performance (performance appraisal) is the process by which organizations through or assess employee performance. This activity can improve personnel decisions and gives feedback to employees about their operations. (Hani Handoko, 2014: 135 )

While the purpose and intent of my conduct research office Dispora Lamongan is I want to know how big the influence of a work culture that is applied at the office Dispora Lamongan in order to raise a work performance of an employee and to serve as the basis or guidelines for each employee in performing their duties. It is one of the reasons why I conducted research in Lamongan Dispora office.

Based on the above, then the problem can be formulated as follows : Is the work culture $(X)$ discipline ( $\mathrm{X} 1$ ) cooperation ( $\mathrm{X} 2$ ) openness $(\mathrm{X} 3)$ is partially on work performance $(Y)$ ? Is the work culture $(X)$ discipline $(X 1)$ cooperation $(X 2)$ openness (X3) simultaneously on job performance ( $Y)$ ? And Which of the work culture variable (X) discipline (X1) cooperation ( X2) openness ( X3 ) the most dominant influence on the increase in job performance ( $Y$ ) Dispora Lamongan employees? 
The purpose of this study was to determine whether the work culture, discipline, openness, and cooperation have a partial effect on the performance of Dispora Lamongan employees. To determine whether the work culture, discipline, openness, and cooperation has a simultaneous

\section{METHODOLOGY}

The time which is used by the author in the study either the start of the title, the survey until the end of the completion of the thesis is to start from January to June 2016. The research was conducted at the office of the DISPORA (Department of Youth and Sports ) Lamongan J1 . Kusuma Bangsa No. 32 Lamongan .

In this study population were taken in this study were all employees of Dispora Lamongan totaling 50 people. In this case the number of samples taken was 50 employees. The sampling technique used in this study is saturated due to the sampling technique in this study all members of the population used as a sample. (Sani and Mashuri 2010: 188 )

The technique of data collection, the writer uses the method research approach. In obtaining the data or collect data is finished preparation of this paper are as follows: Observation, Documentary / Documentation, Questionnaire / Questionnaire.

Operational research variables are basically everything that shaped what is set by the researchers to be learned in order to obtain information about it, then drawn conclusions. Sugiyono (2014: 38). In this study, there are two basic concepts that will be the subject of research by the author of the concept of work culture $(X)$ and the concept of job performance $(Y)$. The concept of working culture is composed of the variables are variables independent / free namely discipline (X1), Openness (X2), and Cooperation (X3). While the concept of job performance $(Y)$ consists of one variable is the dependent variable / bonded.

The data collection technique is a technique or ways used by researchers to collect data. In accordance with a study determine the effect of independent variables on the dependent variable. Analysis of the data that is used aim to study the truths hypothesis. While the method of analysis used to assess the hypothesis is statistical method, the decision to accept or reject a hypothesis. The analysis technique used is Test Validity, Reliability Testing, Regression, Correlation, Coefficient of Determination, $\mathrm{t}$ Test, and Test $\mathrm{F}$. effect on work performance of employees Dispora Lamongan. To determine which of the Culture of variable work, discipline, openness, and cooperation that has most dominant influence to employee work achievement Dispora Lamongan .

\section{DISCUSSION}

Based on the analysis results can be interpreted as follows :

1. Test the validity indicates that the value of $r$ count of each variable is greater than $r$ table of 0.279 . So we can conclude that each item is a valid statement.

2. Reliability test showed that the Cronbach alpha value of each variable constructs or greater than 0.60 , which means a questionnaire that is indicators of these variables is reliable.

3. From the multiple regression analysis obtained a regression equation as follows :

$\mathrm{Y}=1,179+1,340 \mathrm{X} 1+0,578 \mathrm{X} 2+0,783 \mathrm{X} 3 \mathrm{a}=$ 1.179 is a constant which means that if the independent variables in the study ( discipline, openness, and cooperation ) influence $=0$, then the result of the Job Performance is equal to 1.179 .

$\mathrm{X} 1=1.340$, meaning that if discipline is increased one unit or one unit then work performance will rise or increase of 1,179, assuming other variables affecting held constant $(a$, $\mathrm{x} 2$ and $\mathrm{x} 3=0)$.

$\mathrm{X} 2=0.578$, where disclosure is raised one unit or one unit then work performance will rise or increase of 0.578 assuming other variables affecting held constant $(\mathrm{a}, \mathrm{x} 1$ and $\mathrm{x} 3=0)$.

$\mathrm{X} 3=0.783$, meaning that if the cooperation factor increased 1 point or 1 unit, the decision of entrepreneurship will rise or increase of 0.342 assuming other variables affecting held constant ( $a$, $\mathrm{x} 1$ and $\mathrm{x} 2=0$ ) .

So it can be concluded that the most dominant factor in driving performance factor is discipline with a regression coefficient of 1.340 .

4. From the coefficient of determination can be seen that the coefficient of determination ( $R$ square) obtained at 0.938 . This means that $93.8 \%$ dependent variable is the job performance can be explained by the independent variable. That discipline, openness, and cooperation. As well as the remaining $6.2 \%$ job performance could be explained by other variables / factors.

5. From the test results obtained $t$ count variable $\mathrm{t}$ discipline ( X1 ) $8.6941 .678 \geq \mathrm{t}$ table, openness variable ( X2 ) $\geq 4,656 \mathrm{t}$ over 1,678 tables and variable cooperation ( X3 ) $7.4981 .678 \geq \mathrm{t}$ table . 
So it can be concluded $\mathrm{H} 0$ rejected and $\mathrm{Ha}$ accepted which means discipline variable ( X1 ), openness ( $\mathrm{X} 2$ ) and cooperation ( X3 ) has a significant partial effect on work performance ( $\mathrm{Y}$ ) employees Dispora Lamongan .

6. From the test results obtained F F count equal to $233.739 \mathrm{f}$. The table is $\geq 2.81$ with a significant level of less than 0.05 is 0.000 . This means that the independent variable consists of variable discipline ( X1 ), openness ( X2 ) and cooperation $(\mathrm{X} 3)$ simultaneously on job performance ( $\mathrm{Y}$ ) employees Dispora Lamongan .

7. From the simultaneous correlation test can be concluded that the factor of discipline, openness and cooperation jointly have a strong relationship to the level of performance that is equal to 0.969 ..

\section{CONCLUSIONS AND RECOMMENDATIONS}

\section{CONCLUSIONS}

Based on the description of the results of research and discussion, then a number of conclusions from research on Cultural Influence Work to increase employee work achievement Dispora Lamongan is as follows : Dispora Lamongan.

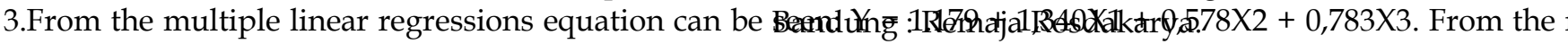
enhance the work performance of employees. Besides, the standard discipline beta coefficient of 0.529 has the greatest value compared with other variable regression coefficient (openness and cooperation). Thus it can be concluded that the most dominant factor influencing performance is variable discipline.

\section{RECOMMENDATIONS}

Based on the research results can be submitted several suggestions are as follows :

1.Achievement of employee dispora is influenced by 2. The employee discipline should be put forward by the management office . based on research conducted by multiple factors evident that discipline is regarded as an influential factor on the performance of the office Dispora .

3. Future studies are expected to develop this research by adding other variables that are considered to affect the relationship Working Culture and Job Performance.

\section{REFERENCES}

Badrudin, 2014. Dasar-dasar manajemen. Bandung : Alfabeta

Sutrisno Edy, 2011. Budaya organisasi. Jakarta : Kencana

Torang, Syamsir, 2013. Organisasi \& Manajemen. Cetakan kesatu. Bandung : Alfabeta.

Triatna, Cepi, 2015. Perilaku Organisasi. Cetakan Pertama. Bandung : Remaja Rosdakarya.

Robbins, Judge, 2015. Perilaku organisasi. Edisi enam belas. Jakarta : Salemba empat.

Hasibuan, 2014. Manajemen Dasar Pengertian, Dan Masalah. Cetakan kesepuluh. Jakarta : Bumi Aksara

Dessler, Gary, 2014. Manajemen Sumber Daya Manusia. Edisi empat belas. Jakarta:Salemba Empat.

Achmad dan Mashuri, 2010. Metode Riset Manajemen Sumberdaya Manusia. Cetakan I. Malang:UIN MALIKI PRESS

Sedarmayanti, 2014. Manajemen Sumber Daya Manusia. Bandung : Refika aditama

Yani, Muhammad, 2012. Manajemen Sumber Daya

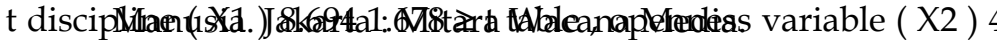

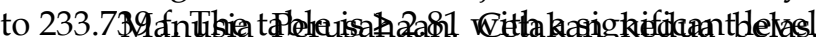

Ghardika, 2012. Pengaruh Budaya Kerja Terhadap Kinerja Karyawan Di Koperasi Karyawan Redrying Bojonegoro (Kareb. Skripsi Universitas Brawijaya

Aini, Nur, 2010. Lingkungan Kerja Terhadap Produktifitas Kerja Karyawan Di Rumah Makan Laka Kull Golokan Sidayu Gresik. Skripsi Universitas Islam Lamongan

Handoko, Hani, 2014. Manajemen Personalia dan Sumber Daya Manusia. Edisi Kedua, BPFE Yogyakarta.

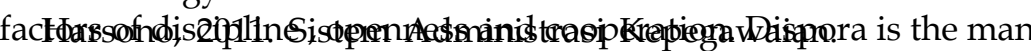
Cetakan pertama. Bandung:FOKUSMEDIA

Sugiyono, 2013. Statistika untuk Penelitian. Cetakan keduapuluh tiga, Bandung:Alfabeta

Sugiyono, 2014. Metode Penelitian Kuantitatif Kualitatif R \& D. Bandung : Alfabeta. 